\begin{tabular}{|c|c|c|c|c|c|c|c|}
\hline ISSN & 0258.2279 & $=$ & Literator & 7 & (1986) & no. & 2 \\
\hline
\end{tabular}

\title{
P. Murgatroyd
}

\section{BACCHYLIDES ODE 3: TRANSLATION AND ESSAY}

\section{OPSOMMING}

In hierdie artikel word Ode 3 van Bacchylides, 'n Griekse digter uit die vylde eeu v.C., vertaal en beskryf. Daar word gepoog om die teks so noukeurig. suiwer en helder as moontlik te vertaal en steeds die essensie van die Griekse teks oor te dra. In die artikel word die gedig in sy historiese konteks geplaas en literér bespreek.

This article concerns the ancient Greek lyric poet Bacchylides (who lived from the end of the sixth to the middle of the fifth century B.C.), specifically his third ode. In my translation, which is based on the Greek text of Snell (1961), I aim above all at accuracy, purity and clarity, and I try to convey to the reader a real idea of the feel and texture of the poem by means of a version that is faithful to the spirit as well as the letter of the Greek. In the essay I provide a résume, explain the background to the piece, discuss its focus, tone and implications, and also treat of its major poetic qualities and characteristics (such as diction, metre, sound, narrative technique, transitions and overall structure). 


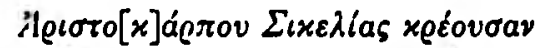

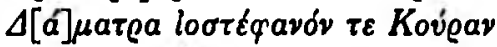

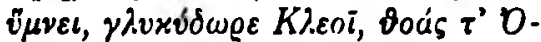

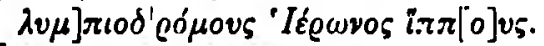

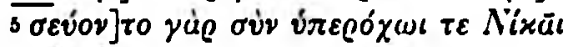

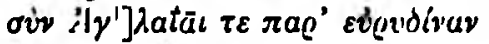

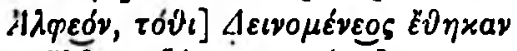

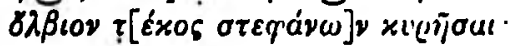

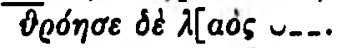

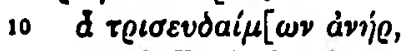

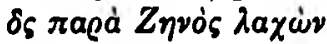

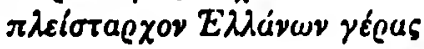

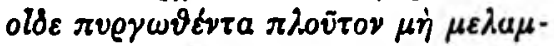

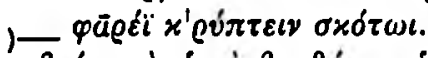

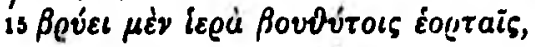

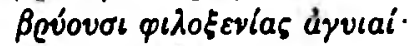

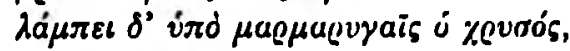

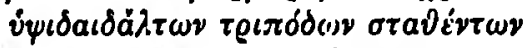

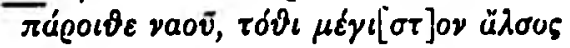

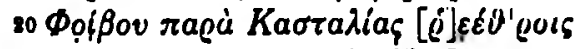

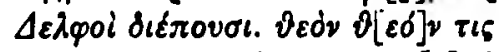

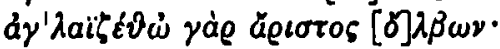

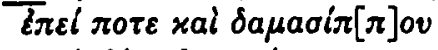
Avoias áexuyétav, $23 \varepsilon \dot{\tau \varepsilon} \tau \dot{\alpha} \nu \pi \varepsilon \pi^{\prime}[\varrho \omega \mu \varepsilon \dot{\nu} a v$

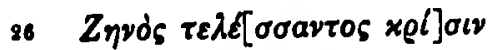

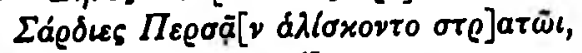

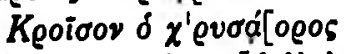

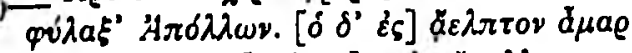
so $\mu[0] \lambda \dot{\omega} \nu \pi 0 \lambda v \delta\left[a ́ x^{\prime} \varrho v o\right]$ !' ov่x $\tilde{\varepsilon} \mu \varepsilon \lambda \lambda_{\varepsilon}$ 


\section{TRANSLATION}

Overjoying Cleo, praise Demeter, cornucopian Sicily's queen, and

the violet-wreathed Maid, and the quick

Olympic-coursers, Hieron's horses.

For with supreme Victory and with Splendour

beside them, they raced along by broad-

swirling Alpheus, where they took the

wreath for Deinomenes' prosperous son;

and the crowd roared

Ah, triply-blessed man, who

got from Zeus the honour

of amplemost rule over Greeks,

who knows how to keep towering wealth unconcealed

by blackmantle darkness!

Lushly shrines are filled with sacrificial feasts

and streets filled with hospitality;

and brilliant with shimmers is the gold

of the tall-ornate tripods sited be-

fore the temple, where the Delphians super-

intend Phoebus' vast precinct by

the stream Castalia. To god, god,

give splendour: that's the best prosperity.

For in the past Croesus, the

ruler of horse-taming

Lydia, when Zeus had

made events turn out as fated

and the Persian army was capturing Sardis,

was saved by Apollo

of the golden sword. On reaching that unex-

pected day, he didn't intend waiting

for sorrowful slavery as well, 


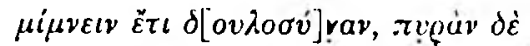

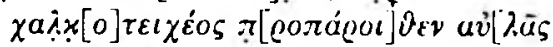

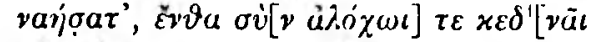

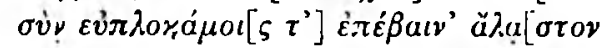

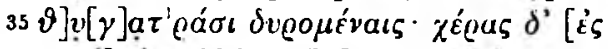
al] $\pi \dot{u}$ !' aivé

$\bar{\gamma} \varepsilon] \gamma[\omega] \nu \varepsilon \nu \cdot, \dot{v} \pi \varepsilon \varepsilon^{2}[\beta \imath] \varepsilon \delta a i \mu o v$, $\tilde{\tau} \dot{\nu}] \bar{v} \vartheta \varepsilon \bar{\omega} \nu \dot{\varepsilon} \sigma \tau \iota[\nu] \chi \alpha ́ \varrho \iota s ;$

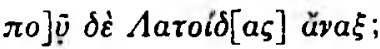

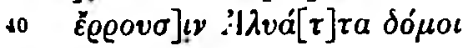

$-v_{-} x_{-} u_{-} x^{-} \mu v \varrho i \omega \nu$

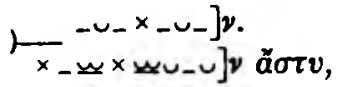

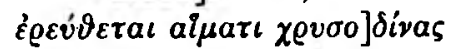

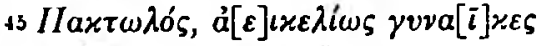

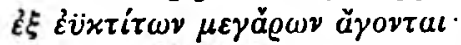

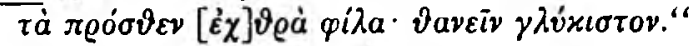

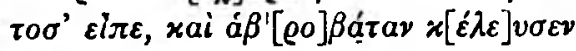

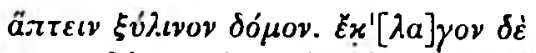

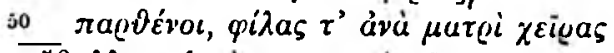

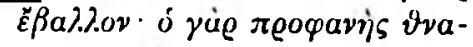

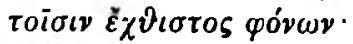

$\dot{\alpha} \lambda \lambda \lambda^{\prime} \varepsilon \dot{\varepsilon} \varepsilon \dot{i} \delta \varepsilon เ \nu 0[\tilde{v} \pi] v \varrho \dot{s} s$

$\lambda a \mu \pi \varrho \dot{v} \delta_{\imath \alpha a ́}[\sigma \sigma \sigma \varepsilon v \mu \varepsilon]_{\lfloor} \circ \varsigma$,

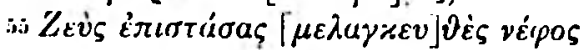

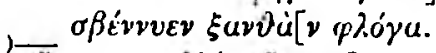

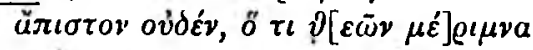

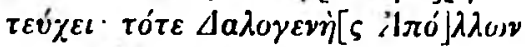

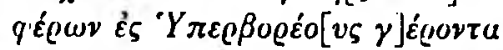

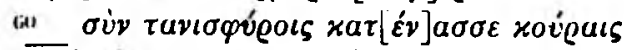

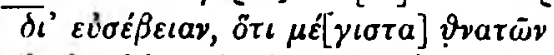

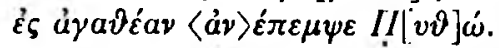

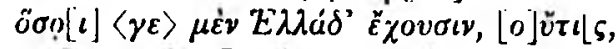

$\dot{\omega} \mu \varepsilon \gamma \alpha i v \eta \tau \bar{\tau} \cdot I \varepsilon \rho \omega v, \vartheta \varepsilon \lambda \gamma^{\prime} \sigma \varepsilon \iota$ 
but heaped up a pyre before his brazen-

walled palace and mounted it with his loyal,

precious wife and with his lovely-haired

daughters, who sobbed inconsolably.

Raising his hands to the high sky, he called

out: "Almighty deity,

where's the gods' gratitude?

Where's Leto's lordly son?

Alyattes' buildings are razed

myriad

city,

golden-swirling Pactolus reddens

with gore, women are driven from the

elegant mansions ignominiously.

What was appalling is welcome: dying's best."

So he spoke, and ordered a silken-

stepping page to light the pyre's wooden

building. The girls screamed, and flung up their hands

to their mother (for the death

they see coming appals

humans most). But as the

brilliant fire of awesome might rushed

from end to end, Zeus placed above a blackbeset

cloud and quenched the blond flames.

Nothing accomplished by caring gods is past

belief. Then Delos-born Apollo

took the old man and his slim-ankled

children to dwell with the Hyperboreans,

for his reverence, since of all humans he

sent hallowed Pytho the greatest gifts.

Yet of all those who inhabit Greece, greatacclaim Hieron, no person will 


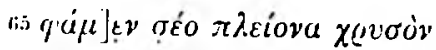

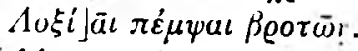

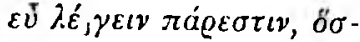

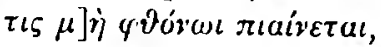

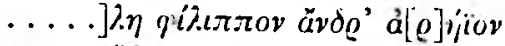

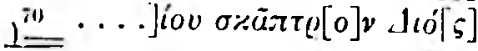

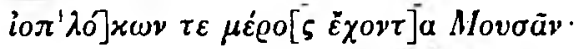
$72 \ldots] \mu a \lambda \dot{\varepsilon} a \iota$. $\pi 0 \tau[\dot{\varepsilon} \ldots . ..] \cdot ! \omega \nu$

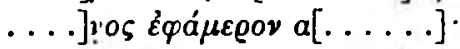

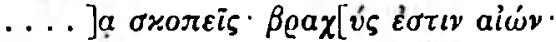

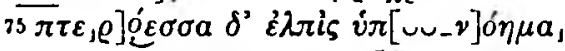

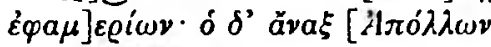

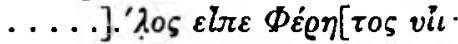

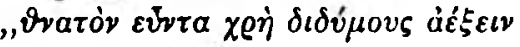

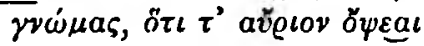

$80 \mu c$ ũvov áliov pảos,

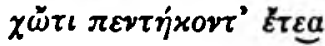

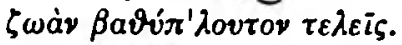

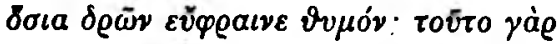

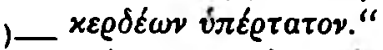

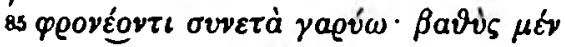

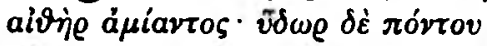

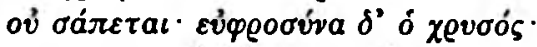

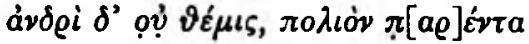

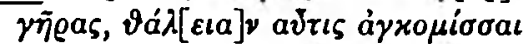

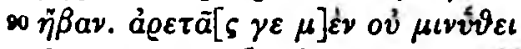

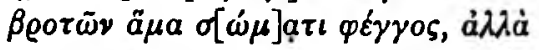

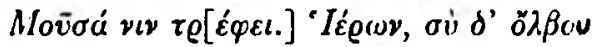

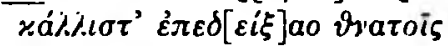

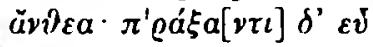

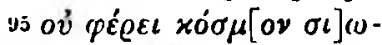

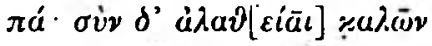

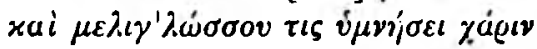
Kitas àndóros. 
say that he has sent more gold

to Loxias than you.

For anyone not fat

with envy it is easy to

speak well of a ... horse-loving, fighting man,

who has a sceptre from

... Zeus and participates with the violet-

haired Muses once

mortal

you look ... Our span is short;

and winged hope ... the thoughts of those who are

mortal; and lordly Apollo said

to the son of Pheres:

"As you are human, you should nurture two

opinions: that you will see

the sun's light tomorrow

80

only, and that you will

lead a wealth-steeped life for fifty

years. Behave piously and enjoy yourself: that

is most profitable."

Words for the wise: steep sky is unpolluted;

sea's water does not decay; gold is

a joy; and it is not permitted

for a man to bypass grey old age and

recover blooming youth. Yet the lustre of

excellence does not fade along with

a person's body: the Muse takes care

of its growth and strength. Hieron, you've shown

humans most glorious flowers

of prosperity; and

silence wins no credit

for the successful: people will

praise with your true glories the grace of the honey-

tongued Cean nightingale. 
Bacchylides 3 is an epinikion, i.e. an ode celebrating a win in one of the Greek athletic games. In Bacchylides and his contemporary Pindar, who also composed epinikia, three major elements can be discerned in such poems: the personal, the mythical, and the gnomic. Their epinikia contain information about the victory and the victor, and often about his family, home and other successes (if any) as well; in a central position comes the narration at length of a myth in some way relevant to the winner's exploit, circumstances or antecedents; and there is also some moralizing (e.g. religious truths, maxims, advice), which frequently permeates the mythical portion too. The present piece concerns Hieron (tyrant of Syracuse on the island of Sicily from 478 to 467 B.C.) and his last and greatest athletic triumph, first place in the chariot-race in the Olympic Games of 468 B.C. ${ }^{1}$

As this is a long and rather involved poem ${ }^{2}$, a summary should facilitate understanding. Bacchylides 3 falls into 3 main sections:

A (1 - 22) Cleo ( a Muse), goddess who gives us delightful poetry, praise Demeter and her daughter Persephone (the Maid), deities who guard fertile Sicily, and praise also Hieron's horses, which were splendidly victorious in the games near the river Alpheus at Olympia (in Southern Greece) and took the prize of the victor's garland for Deinomenes' son, Hieron. That fortunate man has also been given by Zeus the privilege of ruling over more Greeks than anyone else, and he does not conceal but patently uses his great wealth. So (in thanksgiving and to celebrate his win) he has paid for the many sacrifices and public festivities now taking place in Syracuse ${ }^{3}$; so too he formerly dedicated at Delphi (in central Greece) tall and ornate gold tripods (three-legged cauldrons) in

1 For interesting accounts of the ancient Olympic Games and their setting see J. SWADDLING (1980) and M. ANDRONICOS (1976).

2 I should point out that scholars disagree over the interpretation of this epinikion and the emphasis to be placed on various aspects of it. The most I can do here is to point out that I offer only my own views and refer the reader to the bibliography and footnotes below for different approaches.

3 The majority of critics now agree that Syracuse is the most likely setting for lines 15

- 16. but Delphi has also been suggested as the location 
thanks to the god Phoebus (Apollo) ${ }^{4}$. One should honour god so, for this is the most prosperous course to follow ${ }^{5}$.

B (23 - 62) That is shown by Apollo's rescue of Croesus (who ruled from 560 to 546 B.C. and made rich offerings to the gods, especially Apollo) at the time when this king of Lydia ( a country in Asia Minor which was famous for its excellent cavalry) was defeated by the neighbouring Persians and his capital, Sardis, was being captured by them. Instead of enduring the many miseries of slavery, Croesus built a pyre and mounted it with his wife and weeping daughters. He then called out to Zeus ("Almighty deity")", asking why he could see no sign of heaven's gratitude (for his reverence) or of Apollo (the son of Leto), and complaining that the buildings of Alyattes (his father) were being destroyed ... and blood was reddening the Pactolus (Sardis stood on the banks of this river, which swept along gold-dust in its waters), and the women were being led off as captives; he then announced his resolve to die. He ordered an attendant to light the pyre, to screams from his daughters. But as the powerful fire was taking hold, Zeus brought a black rain-cloud ${ }^{7}$

${ }^{4}$ Hieron had dedicated tripods with his brother Gelon in thanks for success in war over barbarian enemies, and possibly a tripod on his own after his victory in the Pythian Games: see GENTILI (1985:72), BRANNAN (1973:193), SMYTH (1963:391), JEBB (1905:452).

5 The (very compressed) Greek phrase in line 22 means literally: "for he/ that is the best of prosperities/ bliss/ happiness". It seems to me that the most likely and apt sense here is the one which I have offered, especially in view of the sentence at $23 \mathrm{ff}$. Which is immediately presented by way of explanation and justification, but other possible translations have also been suggested [LEFKOWITZ (1976): "for he (i.e. god) is the best of prosperities"; FRAENKEL (1975): "for his (i.e. god's) blessing is the best"; TRYPANIS (1971): "for he (i.e. god) is the first in blessedness"; CAMPBELL (1982): "for that is the best of prosperities", i.e. the prosperous man who gives gifts to god is the best prosperous man; LATTIMORE (1960): "for over fortunes his (i.e. god's) power is greatest"; FAGLES (1961): "man's wealth rides on that glory"]

6 Some take "Almighty deity" in 37 as a reference to Apollo or Fate, but if that phrase is an address to Apollo the switch to the third person when alluding to him in 39 is odd, and Croesus would have less reason for complaining to Fate than to a god. Zeus seems a more likely addressee, especially since his conjunction with Apollo in 39 would then be picked up at 55ff., where those two act in concert (as they had appeared together at $25 \mathrm{ff}$.).

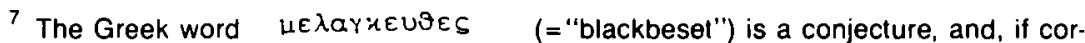
rect, is aptly rather mysterious. Its precise force here is not certain: Liddell and Scott (1968) explain it as "carrying darkness (i.e. dark rain) in its bosom." Jebb (1905:260) translates it as "carrying rain in its dark bosom", while others take it to mean "black and enveloping (the pyre)". 
over it and put out the flames with a downpour. Then Apollo, who was born on the Greek island of Delos, took Croesus and his daughters off to live in the earthly paradise (in the far North) of the legendary Hyperboreans ${ }^{8}$ because that devout king sent greater offerings than any other human to his temple at Delphi (Pytho).

C (63 - 98) Of all Greeks, however, illustrious Hieron has dedicated the most gold to Apollo (Loxias). Unless one is filled with envy, it is easy to praise Hieron, who is ... fond of horses and a fine soldier, who enjoys the kingly power bestowed on him by Zeus, and has an interest in poetry ... The son of Pheres (i.e. Admetus, a mythical king of Thessaly in northern Greece) was once given the following advice by Apollo (who was ordered by Zeus to serve as Admetus' herdsman for killing the Cyclopes, who made Zeus' thunderbolts): "Since you are a human (and humans' lives are limited but of uncertain length), you must accept that it is equally possible that you will die tomorrow or after a life of great wealth lasting many years. Therefore it is best to be pious (because piety is rewarded by heaven, in life and/or after death, whereas impiety is punished) and to enjoy yourself (while you can)." Now I have some remarks that will be intelligible to the wise: (just as it is true that) the sky on high is not polluted and the sea is not subject to decay and gold gives us delight, (so it is also true that) a man may not avoid old age and regain youth. ${ }^{9}$

8 The Hyperboreans were supposed to be immune from disease and ageing, and free from toil and battle, and to spend their days in song, dance, revelry and worship of the gods (see in particular PINDAR, Pythian 10.29ff.).

9 Scholars have written at wearying length about $85-89$ and have offered numerous and widely differing interpretations. I feel (and so apparently does LEFKOWITZ (1976:137) that the explanation which is easiest and which integrates the lines most smoothly is to take it that all four clauses from "steep sky ..." to "... youth" are intended as statements of undeniable and unalterable facts and that the author is saying that just as the first three are undoubtedly and immutably true (before the pollution of the twentieth century), so is the fourth. Admittedly such a point is not immediately clear and one needs to ponder the lines to see it, but then that is precisely why Bacchylides prefaces his remarks with "Words for the wise:" (literally: "I speak things intelligible to a wise man").

Other views of the passage can be grouped together under five main headings. (1) The text is at fault and needs to be corrected (but none of the various emendations proposed is necessary or in fact an improvement). (2) Bacchylides is trying to say that like the sky and the sea (but unlike man) gold is indestructible, but he blurs this with the weak "gold 
But, although the body wastes away, the brilliant fame of excellence does not fade with it, thanks to poetry. Hieron, you have made glorious open use of your prosperity, and success like yours deserves to be celebrated and honoured, and when in the future people praise your genuine glories they will also praise the grace of Bacchylides, the sweet-singing poet (nightingale) from the island of Ceos who told of them ${ }^{10}$.

It will be clear from the above résume that Hieron's victory is mentioned in some detail and is given pride of place: the opening nine lines concern his homeland and his success at Olympia, and more than six of them refer specifically to this triumph (which is also alluded to in $15 \mathrm{ff}$.,

\title{
Continue from page 10
}

\begin{abstract}
"is a joy" where he really means "gold is a joy for ever" (but such a fault would be surprising in an otherwise competent and polished poem, his point here can be explained differently and does not have to be the indestructibility of these three elements - see above - , and in any case he does not actually say that the sky is indestructible but that it is not polluted). (3) The poet is saying that just as sky and sea never change their nature, so gold remains what it is - a joy for ever (but the words "remains" and "for ever" are not present in the text, and in fact Bacchylides does not even include the verb "is" here but says simply "and gold a joy"). (4) The list of imperishable substances contains only twc items (sky and sea), and gold is considered not as an imperishable element but as a possession, and the possession of it is enjoyable but (unlike the proper use of it, presumably) is of limited value in the face of human impermanence (alluded to at $87 \mathrm{ff}$.), i.e. Sky and sea do not perish. (The possession of) gold is a joy, but (not a joy for ever because) man cannot regain his youth (but, if this was the author's point here. he could have expressed it much more clearly and not left us to read in so much, and in any case he does not actually state that the sky is imperishable). (5) Other theories are wilder and more contorted (for them see MAEHLER (1982:57), CAREY (1977:69) and CARSON (1984:116)
\end{abstract}

10 The most natural and obvious interpretation of $96-98$ is that of JEBB (1905:266) and CAMPBELL (1982:423) and I follow them here. FRAENKEL (1975:464), MAEHLER (1982:60) and WOODBURY (1969) disagree and propose various alternative translations, but in my opinion their objections are unfounded and poorly argued: I see no reason why Bacchylides should not work in after all his praise of Hieron a brief and modest reference to his own grace (for parallels see CAMPBELL (1982), assuming that posterity would be acquainted with Hieron's glories mainly from his own graceful poetry: given that, the best sense is provided by taking auv diasicia naizi as "and together with the realities of glories" (i.e. together with Hieron's glories, which are genuine glories), which is a perfectly acceptable translation on the analogy of Thucydides 6.33.1 (and I do not see why the poet must have in mind here the derivation of a $\lambda$ hise 1 a from d privative and $\lambda \mathrm{HOn}$ and must want the word to mean something like "mindfulness" or "disclosure" rather than "reality"). See also PERON (1978:335). 
69 and $94 \mathrm{ff}$.). However, the win in the chariot-race is not the main focus or the most important element in the poem, but seems to be viewed rather as the latest splended addition to Hieron's many splendid achievements. So as well as speaking highly of the Olympic victory, the ode frequently speaks highly of many other aspects of the man (especially his prosperity, proper employment of his riches, and piety). But amid all the opulence, glory and splendour there is a darker undercurrent. Bacchylides shows concern for the tyrant as well as admiration for him, and this is as much a poem of consolation and advice as it is an eulogy. Hieron had been ill earlier and died about a year after this epinikion, and one gathers from Bacchylides' remarks here that at the time of composition his patron was seriously ill. ${ }^{11}$

Thoughtfully and discreetly there is no specific mention of his troubles and the comfort and admonition are offered indirectly and Hieron is left to reflect and make his own inferences. So the laudatory comments could well prompt the tyrant to take solace from all he has accomplished and from his goodness. He should also have found much food for thought in the story of Croesus and Apollo's speech to Admetus, and in both cases links are established with Hieron's own situation (see below). In the former passage (23ff.), with its extensive sadness, Hieron is confronted squarely with adversity and the limitations of human and power; he is also presented with the picture of the Lydian king behaving nobly in the face of catastrophe and imminent death and accepting (even welcoming) his end; and he is shown reverence rewarded in seemingly hopeless circumstances, as Croesus because he was so munificent to Apollo (like Hieron himself: see 17ff., 63ff.) is miraculously saved from death and given happiness instead (in the form of blissful immortality) thanks to the intervention of Zeus (who also favours Hieron: see 11f., 70f.) and Apollo' ${ }^{12}$. In that deity's words to Admetus at 78ff., mortality and human limitations are again to the fore, but this time there is coun-

12

This is the only surviving victory-ode in which the central mythical portion concerns a real and recent historical figure. Thereby the author may well be trying to make the prospect of similar divine rescue in Hieron's case seem more capable of realization (hence too the inclusion of the comment at $57 f$ ). 
sel rather than rescue ${ }^{3}$, as Apollo advocates that a person should spend what life he has being devout and cheerful, points out that one may die tomorrow but cannot be sure when the end will come, and raises the possibility of living on for many years enjoying wealth. The remaining lines (85ff.) are also opposite to the tyrant: there the poet remarks that the ageing process is part of man's inescapable lot and one may not recover the vigour of youth, but poetry keeps a person's reputation alive and thriving, thereby providing one form of immortality, and this the author definitely promises Hieron by means of his poetry.

So, while paying attention to the Olympic victory, the ode goes further and deeper than that alone. It raises some profound questions (in connection with our aspirations and achievements, for instance), but the moralizing in general is not stern or superior or elevated but quiet and simple and down to earth. In addition there is the tale of Croesus, which is in itself interesting and is made still more gripping by Bacchylides' narrative powers. The poet's other technical skills are also much in evidence throughout, and the structure, diction and metaphors are particularly noteworthy.

For many reasons, then, this epinikion could reasonably have been expected to cheer, stir, interest and entertain Hieron. A more detailed examination of the ode should make this still clearer.

In an aptly rich and impressive opening sentence, which refers to three august deities, contains several bulky and unusual compounds, and is not without sonority, the author introduces the victory and several other major themes of the victory-ode (prosperity and the gods' power and beneficence, which are to the fore in this section, and poetry and death (Persephone was also queen of the Underworld), which are picked up later). Although at $1-4$ there is a shift from the divine to the secular, it is a glorious exploit which constitutes this secular element, and there

13 It is possible that Bacchylides wanted his patron to think of the famous story of how Apollo enabled Admetus to escape death when in his prime and live on to old age in reward for the man's goodness and devoutness (see especially Euripides' Alcestis). As far as we can tell, our poet does not openly refer to that tale in this piece, but the god's recent intervention in Croesus' case, the conjunction of Apollo and Admetus here, and the allusions to mortality and piety may have been intended to suggest that legend. If this was the purpose, Bacchylides was hinting at prolongation of life rather than immortality this time 
seems to me to be a smooth enough transition from the goddesses who rule and guard Sicily to Hieron (their priest, and ruler of Sicily's leading city) and his Olympic success, as the poet moves from the powers responsible for one aspect of the tyrant's prosperity to the horses responsible for another (the latest addition to it) ${ }^{14}$. The second sentence depicts a bright and marvellous scene (with the dramatic roar of the spectators), as it expands on and builds up Hieron's win, staying with the horses initially, bringing in more movement and more goddesses (these personifications also help maintain the elevated tone), and now commenting openly on the tyrant's well-being. That comment is taken up in the following lines, which contain further eulogy ${ }^{15}$, and which direct us to different aspects of his fortune and to his (overt) use of it (for this to Bacchylides is even more significant than his possession of it). The expression here is at several points forceful, particularly in $13 \mathrm{ff}$. (in addition to the diction and the (mixed) imagery, note the sound of the Greek: öide pyrgōthenta plōuton mẽ melamphārei kryptēin skotōi). At $15 \mathrm{ff}$. the author goes on to adduce examples of his patron's open employment of his riches and thus continues the laudation, introducing the important motifs of piety and generosity. The switch from Syracuse in $15 \mathrm{ff}$. to Delphi in $17 \mathrm{ff}$. is rather surprising (and so lively), although in the latter lines Bacchylides is in fact giving another (earlier) instance of similar munificence and gratitude to heaven on Hieron's part ${ }^{16}$; then in 21 we move smoothly to a maxim which is a keynote of the ode. In these final lines of the section 15ff. emphasize the extravagance of the festivities, and $17 \mathrm{ff}$. concentrate on opulence and brilliance (three words in 17 denote brightness, and the effect is heightened by the contrast with 14), and then that long sentence gives way to two short phrases which are variously stressful and vigorous.

In addition to the easy progression noted above, the opening part of the poem is rounded off by ring-structure: the word "where" is present in

${ }^{14}$ Contrast JEBB (1905:253) who sees a certain crudeness in the close conjunction of Demeter and Persephone with the horses, and note that the actual mention of the horses is delayed until the very end of 4 .

15 It has been suggested that $10-14$ are a quote of the spectators' words. This is possible, but the language and metaphors seem more appropriate to a poet than a crowd (especially and excited crowd), and Bacchylides at the time of composition had more obvious reasons for making such remarks (see 15f.) than the people at the time of victory. 
19 and 7 , "by the stream Castalia" (20ff.) echoes "by broad-swirling Alpheus" (6ff.), "splendour" occurs in 22 and 5, "prosperity" in 22 recalls "prosperous" in 8, and the references to Phoebus and god at the end parallel the deities at the start.

The transition to the victory-ode's central portion is smooth: at 23ff. Apollo's protection of Croesus (who was renowned for his munificence to the god: see 61ff.) shows immediately that the myth illustrates 21ff., and because of that king's reputation for wealth, devoutness and rich offerings at Delphi the opening sentence of the myth contains various implicit links with the lines preceding it; explicitly Zeus (25) and Apollo (28) take up "god, god" in 21 and "Phoebus" in 20, as "of the golden sword" (29) picks up "splendour" in 22 and "gold" in 17; so too from the outset close correspondences between Croesus and Hieron are implied (by means of the former's titles to fame just mentioned) and established (i.e. Apollo, Zeus, horses and kingship, with "ruler" in 24 calling to mind "rule" in 12).

As well as being instructive for Hieron (see above), the story of the Lydian king engages. The author's clear and flowing narrative contains many graphic and realistic touches, but it is particularly noteworthy for its drama and pathos. The poet takes up at the point when Sardis is just being captured, and makes his first sentence even more dramatic by delaying Apollo's aid. From then until the final words of this whole passage he concentrates on a few significant moments as the king and his family face death. At 29ff., as the swiftly acting Croesus actually mounts the pyre with the others, various details contribute to the sadness, especially the presence of women ${ }^{17}$ (the impending death of the women is tragic in itself and also means that the monarch's line will be completely obliterated), the epithets for the wife and daughters, the great grief of the latter, and in "brazen-walled palace"18 the notion (which appears at several other points in this section) of opulence, power and splendour now eclipsed and counting for nothing. Having already

17 FRAENKEL (1975:467) believes that "the king has decided to make his entire family a sacrifice to his pride", but such an interpretation would represent Croesus in an unsympathetic light, and it seems to me more likely that the monarch's purpose is to save the women too from "sorrowiul slavery".

18 The walls may be made of solid bronze or may just have bronze plates attached to them: see MAEHLER (1982:47); LEFKOWITZ (1976:129). 
shown the king's moving bravery and proud dignity in his choice of death before slavery, at $37 \mathrm{ff}$. Bacchylides expands on that in an immediate and emotional speech which opens with insistent questions, moves on to a staccato and direct recital of the horrors taking place at that very time, and closes with a brisk and bald statement of Croesus' resolve to die. His words not only reveal his bewilderment and unhappiness (in justified but still respectful complaint) and his strength and nobility of character ${ }^{19}$ but also heighten one's awareness of the tragedy of the situation. At 48 - 55 in a rapid series of short clauses and sentences the narrative becomes even more affecting and tense: the (solitary) exquisite, gliding attendant ("silken-stepping page") is now used for a new and terrible task, there is the antithesis between "the pyre's wooden building" and "Alyattes' buildings" (40), there is focus on the women again (and the daughters whose youth is brought out, scream and turn futilely to their mother), and at 54ff. there is a collocation of words denoting danger as the drama and suspense reach their highest pitch. Then in a sudden climax of marvel and joy come the interventions of Zeus (with the vivid contrast between the cloud and the flames) and Apollo, which are described in each case with a skimming of detail and a brevity that suggest well supernatural speed and effortless ease ${ }^{20}$, and which are separated by another aside (compare $51-53$ ) that seems to have relevance for Bacchylides' patron, and which are followed by two lines stressing the devoutness that was rewarded and preparing for movement from the legend back to the Sicilian tyrant.

The structure of this mythical portion also deserves comment. The core is the speech at $37-47$, and on either side of that there are two groups of lines very nearly equal in length and two rings. In the inner frame there is adversity and a mood of sadness, as Croesus is depicted with his wife and grieving daughters about to die on the pyre, and hands are raised. In the outer frame there is deliverance from catastrophe and relief, together with action on the part of Zeus (without an adjec-

\footnotetext{
9 I cannot agree with those critics who see here harsher and darker emotions such as bitterness, despair and rage at heaven, especially since Croesus was actually rescued by Zeus and Apollo after this speech and his conduct is being held up for Hieron's examination and (presumably) imitation.

20 Contrast FRAENKEL (1975:465), who feels that the denouement fails to achieve its full effect because the poet disposes of the rescue and transfer to the Hyperboreans 100 hastily and too summarily.
} 
tive) and Apollo (with an epithet, and aiding the monarch), while the gold of Apollo's sword is paralleled by the yellow of the flames.

At $63 \mathrm{ff}$. the poet dexterously introduces the final section, gliding from Croesus, who gave Delphian Apollo the greatest offerings of all humans, to Hieron, who has given him the most gold of all Greeks, echoing "greatest" (62) in the bold "greatacclaim" (64), and repeating "sent" (62 and 65). After praising the tyrant's renown and reverent munificence at $63-66$, he then progresses to other praiseworthy features of the man, listing several together for impact. In both these sentences the correspondences between the Lydian and the Sicilian are reinforced. Because of the gap in the text we have lost the train of thought from 72 up to Apollo's address to Admetus, another person with whom the tyrant has points in common (Bacchylides here specifies mortality, wealth and Apollo, and in legend Admetus was a king famed for his piety). These parallels again highlight the relevance of the passage to the poet's patron. The words are given weight by being put in the mouth of Apollo, the august and wise god of prophecy (whom Hieron clearly respected), and because one has to work out for oneself their precise implications (for which see the summary above) they have an aptly oracular flavour (oracles were often enigmatic) and also attract attention. Still more arresting are the lines that follow (85ff.). There initially the imposing and puzzling terse clauses (for the point see the résumé) look like an abrupt departure from what preceded them, but it eventually becomes clear that the author is in fact picking up the theme of the human condition in Apollo's address and developing it in a similar vatic fashion (and there are also links in the recollection of "the sun's light" $(80)$ in "sky" and "gold", of "wealth-steeped" (82) in "steep", and of "enjoy" (83) in "joy"). The manner here is Pindaric, and in fact Bacchylides seems to adapt two passages in Pindar: at Olympian 2.83ff. he had described his remarks as "swift arrows ... that speak to the wise", and he had begun Olympian 1 with the following images of supremacy: "Water is excellent; gold, like fire flaming at night, outshines other lordly wealth; and if, my heart, you are eager to tell of athletic prizes, do not look for another bright star by day in the lonely sky more warming than the sun, and we will not speak of any games as greater than the Olympic ones". At $89 \mathrm{ff}$. our poet goes on to conclude his epinikion on a more positive and optimistic note, blending compliments with consolation once more. The logical progression there has already been indicated and does not need to be handled again, but the final two and a half lines do deserve further comment. The author signs off with a personal (but modest enough) 
touch and with a striking and expressive reference to himself as "the honey-tongued Cean nightingale". The nightingale is unpretentious and melodious, and, as the bird was connected with sadness in ancient thought, ${ }^{21}$ there may be allusion here to the melancholy strain in Bacchylides' poetry as well. It is also possible that he has in mind again Pindar, who at Olympian 2.86ff. had likened himself to the eagle (which is a more grand, impressive and powerful bird, but nothing like as fine a singer) and had quite possibly compared Bacchylides and his uncle Simonides to a pair of chattering crows. At any rate the final lines are appropriately musical (in the Greek: siōpā. syn d'alāthēiāi kalôn kãi meliglōssōu tis hymnēsēi charin Kēiās aēdonos).

Ring-composition is once more in evidence, not only within the last section but also within the ode as a whole: $63 \mathrm{ff}$. are taken up at the end by the address to Hieron, the mention of his riches and achievements and of praise of him, "Muse" in 91 ("Muses" in 72), "flowers" in 93 ("violet"' in 71) and "Cean" in 98 ("Greece" in 63); 1ff. is echoed in references to Hieron's success and prosperity, "Muse" in 91 (compare the deities at the start, especially Cleo), "Hieron" in 92 ("Hieron's" in 4), "flowers" in 93 ("violet-wreathed" in 3), "prosperity" in 94 ("prosperous" in 8), "praise" in 97 ("praise" in 1) and "Cean" in 98 (compare the island Sicily in 2). Furthermore, there are numerous words and themes which appear in all three parts of the epinikion, binding it together and often making for interesting developments (such as contrasts): the more obvious terms and motifs embrace gods, piety, wealth and prosperity, but there are also less obvious ones, embracing liquids, sounds, horses, brightness and darkness, for example ${ }^{22}$.

One final element of the poem which seems worthy of note is its metre. The ode is made up of seven identical groups of 14 lines. Each of these groups consists of units of 4,4 (both the same) and 6 lines successively. In the units of 4 lines the second and third lines are metrically parallel, but the first and fourth are different (producing the scheme $a \mathrm{~b} \mathrm{~b} c$ ); in the units of 6 lines the second, third and sixth lines are metrically equivalent to each other, but the other lines are dissimilar (making the pattern $d e$ e $f \mathrm{~g} \mathrm{e}$ ). Thus the overall system of the group of 14 lines

21 See e.g. Homer. Odyssey $19.518 \mathrm{ff}$.

22 See LEFKOWITZ (1976:125) and BRANNAN (1973) for (at times oversubtte) discussion of such verbal and thematic chains 
is : $a b b c ; a b b c ; d$ e e f g e. In my translation I have tried to suggest the effect of the original by a group made up of lines which have the following syllabic count: $11,9,9,10 ; 11,9,9,10 ; 7,6,6,8,12,6$.

\section{BIBLIOGRAPHY}

ANDRONICOS, M. 1976. Olympia. Athens.

BRANNAN, P.T. 1973. Bacchylides' Third Ode. Clasical Folia, 27: $187 \cdot 229$

CAMPBELL, D A. 1982. Greek Lyric Poetry. Bristol.

CAREY, C. 1977 -1978. Bacchylides 3.85 - 90. Maia, 29 - 30:69 - 71.

CARSON, A. 1984. The Burners: A Reading of Bacchylides' Third Epinician Ode. Phoenix. 38: $111-119$.

FAGLES, R. 1961. Bacchylides. New Haven

FRAENKEL, H. 1975. Early Greek Poetry and Philosophy. Oxford

GENTILI, B. 1958. Bacchilide Studi. Urbino

JEBB, R.C. 1905. Bacchylides. The Poems and Fragments. Cambridge.

LATTIMORE, R. 1960. Greek Lyrics. Chicago and London.

LEFKOWITZ, M.R. 1976. The Victory Ode. New Jersey.

LIDDELL, H.G. and SCOTT, R. 1968. Greek-English Lexicon. Oxford.

MAEHLER, H. 1982. Die Lieder des Bakchylides: Die Siegeslieder. Leiden.

PÉRON, J. 1978. Les Mythes de Cresus et de Méléagre dans les Odes III et V de Bacchylide. Revue des Etudes Grecques, 91: 307 - 339.

SMYTH, H.W. 1963. Greek Melic Poets. New York. (reprint)

SNELL, B. 1961. Bacchylides. Leipzig.

SWADDLING, J. 1980. The Ancient Olympic Games. London.

TRYPANIS, C.A. 1971. The Penguin Book of Greek Verse. Hammondsworth.

WOODBURY, L. 1969. Truth and the Song: Bacchylides 3.96 - 98. Phoenix, 23: 331 - 335. 